\title{
JUSTICE FOR PERSONS WITH DISABILITIES (PwDs) IN INDONESIA
}

\author{
Zainal Abidin Pakpahan \\ PhD in Law Program, Graduate School \\ University Of Sumatera Utara \\ Medan, North Sumatra, Indonesia \\ zaepph@yahoo.com
}

\author{
Ningrum Natasya Sirait \\ PhD in Law Program, Graduate School \\ University Of Sumatera Utara \\ Medan, North Sumatra, Indonesia \\ ningrum.sirait@gmail.com
}

\begin{abstract}
Eliminating discrimination against Human Rights has been universally regulated as stated in Declaration of Human Right in 1948, including the elimination of discrimination against persons with disabilities (PwDs). Furthermore, in Indonesia, there are some laws on human rights such as Law Number 39 of 1999 on Human Rights and Law Number 8 of 2016 on Persons with Disabilities. Unfortunately there is no special court for certain human right violation as needed by persons with disabilities. Although there is Law Number 26 of 2000 on Human Rights, the law is only applicable for the Gross Human Rights Violations such as genocide and crimes against humanity.
\end{abstract}

There is a discrimination case which relates to ECOSOC rights of persons with disabilities. The case in $\mathbf{2 0 0 5}$ was about the prohibition for a person with disabilities to register as a candidate of civil servant in Surabaya. The person who was not allowed to apply for the job did not challenge the prohibition since the public pressure was much harder on that situation. There was no court case but the government agency changed the requirements and accepted persons with disability. Indonesia needs to strengthen and enforce the law more strictly.

Keywords-justice, persons with disabilities (PwDs), human rights violations

\section{INTRODUCTION}

Discrimination in the regulatory framework as a violation of human rights can be explained in Article 23 of the Universal Declaration of Human Rights of 1948, then Article 28 Paragraph (2) of the 1945 Constitution, and Law Number 39 of 1999 on Human Rights. Discrimination against persons with disabilities as specific human rights violations produces many relevant regulations on international discrimination and convention, thus motivating the issuance of Law Number 8 of 2016 on persons with disabilities.

Discriminations as human rights violations constitute a practice or treatment committed by an individual or a group, including those committed by the state apparatus, whether intentionally or unintentionally, or due to negligence which legally reduces, hinders, limits, and/or deprives the rights of an individual or a group guaranteed by law and not obtained or feared not to obtain a fair and just legal settlement under the prevailing legal mechanisms.

Human rights violations of discrimination for persons with disabilities are human rights violations in addition to crimes of Genocide and crimes against humanity [1].
Victims of discrimination against persons with disabilities are those who suffer physically, mentally or physically and mentally, or suffer from material losses. A person with disability is any person with physical, mental or physical and mental impairments, which can disrupt or become an obstacle in conducting life activities. As a result of these limitations, persons with disabilities are often considered weak and unable to protect themselves. In addition, they tend to become the victims of injustice by discrimination for disability.

A legal development, which is either in line or not in line with its original rules, cannot be construed as a legal rejection. In this context, one of the examples of discriminatory practice for persons with disabilities as human rights violations is when the Roman law Lex Aquila from 287 BC established sanctions realized in compensation for victims of physical damage to the disabilities caused by discrimination. This regulation was finally adopted by many countries in Western Europe. The legal sanctions mentioned in Lex Aquila applied only to material losses incurred and do not apply to physical damages. According to Justinian, no compensation is established for wounds or deformed bodies because free human body cannot be measured with money [2].

The limitations possessed by the victims usually make it difficult for them to reveal the fact or truth to the crime that happened to them. Therefore, protection for victims is required in the process of human rights trials in Indonesia. This protection refers to a legal protection for persons with disabilities who have the equal rights with other common people to ensure the equitable fulfillment of their rights as citizens.

One of the discrimination cases involving persons with disabilities was experienced by Wuri Handayani, a person with disabilities, who was discriminatively refused by the municipal government of Surabaya to register herself as a Candidate for Civil Servants (CPNS). So, she moved out to protest such discrimination and fight for the rights of the marginal, showing her disagreement with the decision of the municipal government of Surabaya that refused her registration as a CPNS only due to her physical impairment. She was unable to walk and, therefore, had to use a wheelchair. Such limitation made her considered unqualified to register. Finally, her lawsuit was filed to the municipal government of Surabaya through the State Administrative Court of Surabaya Number 10/G.TUN.2005/PTUN.SBY. 
Responding to this lawsuit, the State Administrative Court of Surabaya decided that the interpretation was incorrect because it violated the person's rights through discriminatory treatment, and granted Wuri Handayani's claim as a victim of persons with disabilities [3].

The existence of the Human Rights Court in Indonesia is a reflection that must be able to judge every kind of human rights violations in Indonesia without having to distinguish in its case resolution system which has substantially and clearly been defined as a violation of discriminatory practice against persons with disabilities that belong to human rights violation, and which is not limited to its law enforcement system. Therefore, the existence of the Human Rights Court in Indonesia can eliminate any unjust treatment for persons with disabilities when they become the victims of discrimination, and its role as a human rights court is able to prosecute every practice of human rights violations universally.

\section{RESEARCH METHODOLOGY}

This is an analytical descriptive research using a normative law method. The main data in this study are primary data. The data were collected using a library research. The primary data were analyzed using a qualitative analysis method. The data was, then, interpreted in order to draw conclusions by means of logical inductive reasoning to achieve the expected result [4].

\section{FINDINGS AND DISCUSSION}

\section{A. Justice for Persons with Disabilities as the Victims of} Discrimination

The 1945 Constitution has formulated Article 27 paragraph (1), stating that all persons have equality before the law and has also formulated Article 28 A-J, particularly in Article 28B paragraph (2), and Article 28 I paragraph (2), describing discrimination. According to the principle of equity and equality, both the rich or the poor and the normal or the physically impaired persons shall have equity before the law and this has been recognized in the 1945 Constitution as the highest law (grondwet).

The term "persons with disabilities" or people with different capabilities are often known as "difable" (differently abled people) or are today more commonly known as disabilities, and the problems related to disabilities still rarely receive the attention from governments and communities in Indonesia. Other terminologies used to refer to "difable" include "persons with disabilities", persons with different capabilities, or abnormal persons. Those terms are actually not "value-free", meaning that there is an understanding of certain values that has been imposed by a particular group of people who label and dominate another group of people [5].

Persons with Disabilities, according to the Translated Text of Convention on the Rights of Persons with Disabilities that has been ratified by Law Number 19 of 2011 as amended by Law Number 8 of 2016 on Persons with Disabilities, include those with physical, mental, intellectual, or sensory limitations over the long term who cannot stand facing a variety of obstacles because these obstacles can impede their full and effective participation in a society on an equal basis of others [6].

In this case, gross human rights violations and discriminations against persons have been categorized as human rights violations whose prosecution has been normatively mentioned in Article 7 of Law Number 26 of 2000 emphasizing that only crimes of Genocide and crimes against humanity can be prosecuted in the Human Rights Court, but not prevailing to discrimination for disabilities. An analysis of cases of discrimination against persons with disabilities that happened in Indonesia was found in the Supreme Court Decision Number 595/K/TUN/2005 MA on the rejection on physical impairment to register as CPNS in Surabaya in 2005 , when a disabled person with a wheelchair was rejected to register as CPNS in Surabaya by the Mayor of Surabaya who had announced not to accept and reject persons with disabilities to register as CPNS in Surabaya in 2005.

Then Handayani, who became the victim of discrimination against persons with disabilities, filed a lawsuit to the State Administrative Court (PTUN) of Surabaya because her lawsuit was rejected by the Human Rights Court that had no absolute authority to judge her case and because its authority was limited only to gross human rights violations. In the trial process held by the State Administrative Court, the lawsuit filed by Handayani, the victim of discrimination treatment against persons with disabilities, was granted by the panel of judges of the PTUN. Dissatisfied with such decision, the Mayor of Surabaya Bambang DH filed an appeal to the State High Administrative Court, and his appeal was rejected; then, he continued his effort by filing a cassation to the Supreme Court, and his cassation was also rejected by the Supreme Court [7]. Consequently, such a decision has a permanent legal force that becomes jurisprudence where the result of its decision keeps instructing the Mayor of Surabaya to accept Handayani, a person with disabilities, as a CPNS in Surabaya.

Justice for persons with disabilities when they become the victims of discrimination against human rights violations in Indonesia is still far from expectation because the enforcement of judicial system obviously does not protect persons with disabilities. Therefore, it will be difficult to prove that someone has committed discriminatory treatment against persons with disabilities. In addition, such discriminatory treatment needs to be proved in the court of justice to reveal whether it is truly done [8]. Yet, to prove it in a fair way still encounters a variety of obstacles, one of which is the incapability of human rights court to accommodate the interests of persons with disabilities in terms of raising their rights as the victims of discrimination treatment because the human rights court has been restricted earlier to judge cases of gross human rights violations such as crimes of genocide and crimes against humanity.

Suparman Marzuki stated that, in the elucidation of Law Number 26 of 2000, the formulation of a law on Human Rights Court is based on the consideration that human rights violations are "extra ordinary crimes" and have broad impacts, both at national and international level, and are not criminal offenses set forth in the Indonesian Criminal Code [9]. 
Next, Muladi explains that the differences between gross human rights violations and common crimes is that gross human rights violations are difficult to prove because they are systematically organized, and the proof must be in accordance with international legal standards [10]. Meanwhile, Natabaya says that the responsibility on human rights violations is addressed to individual, not to institution. In addition, human rights violations cause both material and immaterial losses leading to insecurity feelings experienced by individuals and society which need to be immediately restored to realize the supremacy of law in order to achieve peace, order, serenity, justice and prosperity for all Indonesian people [11].

Public equality before the law means that the perpetrators of crimes of gross human rights violations and universal human rights violations, especially discriminatory treatments to persons with disabilities, should be prosecuted in a Human Rights Court, because both of the crimes belong to human rights violations as described in Law Number 39 of 1999 on Human Rights. This is because a law or another form of legislation [12] which is applied is interpreted differently by people, some of them view that the law is fair, but others say it is unfair [13].

The limitations possessed by the victims usually make it difficult for them to disclose the fact or truth to the crime that happened to them. For this reason, it is necessary to provide protection for them in the process of human rights trials in Indonesia. This protection is a legal protection, meaning that persons with disabilities have the same rights as people in general. Therefore, a system of law enforcement applicable to persons with disabilities is absolutely needed to ensure the equitable fulfillment of the rights of persons with disabilities as citizens.

B. Discrimination against Persons with Disabilities as Human Rights Violations Cannot Be Judged in Human Rights Court

Due to a variety of regulation elements formulated to prevent discriminatory practices and treatments that belong to human rights violations, Law Number 26 of 2000 on Human Rights Court is issued as a formal law of Law Number 39 of 1999 on Human Rights. Nevertheless, the authority of the law on Human Rights Court is limited, applicable only to prosecute gross human rights violations but not to prosecute discrimination against persons with disabilities (human rights violations) in accordance with Article 4 and Article 5 of Law Number 26 of 2000 on Human Rights Court. This limitation, then, becomes the reasons for some people to say that discriminatory practices to persons with disabilities cannot be prosecuted in a Human Rights Court, among others;

\section{1) Normative Principles}

Normatively, human rights violations are specifically explained in the Law of Human Rights Court stating that human rights violations that can be judged in the domain of Human Rights Court are those related with crimes of Genocide and crimes against humanity as set forth in Article 4 of Law Number 26 of 2000 on the Human Rights Court that explains [14];
"Human Rights Court has the duty and authority to investigate and decide the cases of gross human rights violations".

Then, Article 5 explains;

"Human Rights Court also has the authority to investigate and decide the cases of gross human rights violations committed outside the territorial boundaries of the Republic of Indonesia by Indonesian citizens".

The normative reason in discriminative cases that cannot be concretely judged in the domain of Human Rights Court is that the regulation through legal instruments is not explicitly contained in the applicable laws and regulations as set out in Law Number 26 of 2000 on Human Rights Court.

2) Reasons of Juridical Foundation as a Form of Establishment of Law on Human Rights Court in Judging Gross Human Rights Violations

Based on the condition of the need for a legal instrument for the establishment of human rights court quickly, the government issued Government Regulation in Lieu of Law (PERPUU) Number 1 of 1999 on Human Rights Court. This PERPUU has become the juridical basis for the investigation of cases of gross human rights violations in East Timor by the National Commission on Human Rights. For various reasons, PERPUU Number 1 of 1999 was later rejected by People's Representative Council (DPR) to become a law. Some of the reasons for rejection of this PERPUU include: (i) Constitutionally, the issuance of PERPUU on the Human Rights Court based on Article 22 Paragraph (1) of the 1945 Constitution which reads "in the case of exigencies compel" which is used as the basis to qualify the existence of urgent matters is considered inappropriate; and (ii) the substance set forth in the Regulation contains limitations and weaknesses [15].

Following the rejection to the PERPUU by the DPR, the government then submits a bill on Human Rights Court. In its Elucidation on Human Rights Court, the following provisions are mentioned [16];

a. It is a manifestation of the responsibility of the Republic of Indonesia as the member of the United Nations. Thus, it is one of the missions that develops moral and legal responsibilities in upholding and implementing the human rights declaration established by the United Nations, and those contained in various other legal instruments governing the existing human rights or the human rights that have been accepted by the Republic of Indonesia.

b. In order to implement the Decree of People's Consultative Assembly (MPR) Number XVII/MPR/1998 on Human Rights and the follow up of Article 104 Paragraph (1) of Law Number 39 of 1999.

c. To overcome uncertain situation in the field of security and public order, as well as the national economy. The existence of human rights court is also expected to restore international and public confidence in law enforcement 
and guarantee of legal certainty on human rights enforcement in Indonesia.

Therefore, among the three reasons mentioned above, the legal basis on the need for the establishment of Human Rights Court to judge gross human rights violations constitutes the second reason. The establishment of Human Rights Court is the implementation of MPR Decree Number XVII/MPR/1998 on Human Rights and the follow up of Article 104 Paragraph (1) of Law Number 39 of 1999. Article 104 Paragraph (1) of Law Number 39 of 1999 on Human Rights and National Commission on Human Rights states that in order to judge gross human rights violations, it is necessary to establish a human rights court within the general court [17].

The limitations possessed by the victims usually make it difficult for them to disclose the fact or truth to the crime that happened to them for which, at the simplest level, litigation court is a means of dispute resolution [18]. Thus, litigation level may measure two societal characteristics - the frequency of, in particular, types of problems and the willingness and ability of individuals to convert disputes in the litigation. However, various theoretical traditions of the relationship between the public and litigation can be examined [19]. In this regard, at the court level, discriminatory practices against persons with disabilities should have been examined and prosecuted in a human rights court showing that both gross human rights violations and discrimination against persons with disabilities are human rights violations which have the same status with human rights violations as described in Law Number 39 of 1999 on Human Rights. Consequently, such treatment results in the equality of rights for protection for all human beings as they obtain universal protection and maximum benefit.

\section{The Existence of Human Rights Court in Indonesia in Judging Discrimination Practices as Human Rights Violations}

Human Rights Court is a Special Court within the General Courts and is located in a regency or municipal area whose jurisdiction covers the jurisdiction of the District Court concerned [20]. The court has the duty and authority to investigate and decide cases of gross human rights violations, and those categorized as gross human rights violations include crimes of genocide and crimes against humanity [21]. In the early common law system, there is no difference between crime and error. The error was classified as (1) felony (serious crimes) and (2) not felony (minor crime) [22].

Based on the substance of Law Number 26 of 2000 on Human Rights Court, it is determined that not all gross human rights violations can be resolved through Human Rights Court although the duty of Human Rights Court is limited only to investigate and decide cases of gross human rights violations [23].

The absolute competence of Human Rights Court is, of course, so narrow that it is impossible to guarantee a satisfactory settlement of cases of human rights violations proposed to be investigated and decided by the Human Rights
Court. In addition, categorizing gross human rights violations into crimes of genocide and crimes against humanity as the only objects of the trial actually reduces the meaning of gross human rights violations in the provisions of Article 104 of Law Number 39 of 1999 on Human Rights. The Law contains provisions on the establishment of Human Rights Court Law stating that to judge gross human rights violations, Human Rights Court is established, while the notion of gross human rights violations mentioned in its elucidation includes genocide, arbitrary/extra judicial, torture, enforced disappearance, slavery, or systematic discrimination [24].

The concept of gross human rights violations is even broader than the similar concept in the Law of Human Rights Court that is limited only to two types of crimes, i.e. crimes of genocide and crimes against humanity. In this context, horizontal synchronization between Article 104 of Law Number 39 of 1999 on Human Rights and Article 4 in conjunction with Article 7, 8, 9 of Law Number 26 of 2000 on Human Rights Court obviously takes place. The solution to this problem in a legal theory with the principle of lex superiori derogat legi inferiori (higher law set aside lower law) precisely justifies Law Number 26 of 2000 which was issued later than Law Number 39 of 1999. Hence, Article 104 of Law Number 39 of 1999, which has broader meanings, is no longer applicable since the enactment of Law Number 26 of 2000 on Human Rights Court [25]. Elucidation of Article 7 of Law Number 26 of 2000 also stipulates that genocide and crimes against humanity are crimes in accordance with the 1998 Rome Statute of the Intent Court. Article 5 paragraph (1) of the Rome Statute defines that crimes in the jurisdiction of the International Criminal Court comprise genocide, crimes against humanity, war crimes, and aggression crimes [26]. If Article 7 of Law on Human Rights Court defines that gross human rights violations only include genocide and crimes against humanity, this means that the legislators deliberately define that gross human rights violations consist only of genocide and crimes against humanity.

Furthermore, the scope of authority of the Human Rights Court does not only regulate territorial principles but also uses active national principles or personal principles. The purpose of these principles is to regulate that Indonesian criminal law or legislation applies to Indonesian citizens committing crimes both within and outside the territorial boundaries of the territory of the Republic of Indonesia. In Law on Human Rights Courts, such principles are implicitly contained in Article 5 stating that Human Rights Court also has the authority to investigate and decide cases of gross human rights violations committed outside the territorial boundaries of the Republic of Indonesia by Indonesian citizens. The scope of authority of the Human Rights Court is limited only by its authority, which makes the supremacy of law in the domain of court difficult to uphold, so that the sense of justice for persons with disabilities is still far from being expected by the Indonesian people. 


\section{CONCLUSIONS}

Justice for person with disabilities against human rights violations is still far from the protection and justice expected by them since the current Human Rights Court has not been able to prosecute any violation of discrimination against persons with disabilities when they become the victims of human rights violations. Normatively, the Law on Human Rights Court still looks "inappropriate" to uphold the supremacy of law on human rights, so it is important to establish a clear legal umbrella for persons with disabilities to obtain equally fair rights in upholding truth and justice indiscriminately. Consequently, it is mandatory to amend the Law on Human Rights Court by issuing new regulations that can accommodate the interests of the disability's rights and prosecute discriminatory treatments for persons with disabilities in the existing Human Rights Courts in Indonesia.

\section{ACKNOWLEDGEMENTS}

The writer would like to thank the provider of Indonesian Lecturer's Domestic Scholarship (BUDI DN) through Education Fund Management Institution (LPDP) that has supported this research, and this research can, therefore, run well. The writer hopes this research would be useful to all Indonesian people.

\section{REFERENCES}

[1] Suparman Marzuki, Pengadilan HAM di Indonesia, Jakarta: Erlangga, 2012, pp. 42.

[2] Alan Watson, Legal Transplants An Approach To Comprative Law, Second Edition, London: The University Of Georgia Press, 1993, pp. 27.

[3] Lihat, Putusan, Mahkamah Agung Nomor: 595/K/TUN/2005 MA, Tentang Penolakan Penyandang Disabilitas Menjadi PNS di Kota Surabaya Tahun, 2005, pp. 5.

[4] Peter Mahmud Marzuki, Penelitian Hukum, Jakarta: Kencana, 2006, pp. 141.

[5] Rahayu Repindowaty Harahap dan Bustanuddin, Jakarta: Jurnal Inovatif, 2015, pp. 18.

[6] Lihat, Pasal 1 Konvensi Mengenai Hak-Hak Penyandang Disabilitas (Convention on the Rights of Persons with Disabilities), telah disahkan dengan Republik Indonesia, Undang-Undang Nomor 19 Tahun 2011 yang sebagaimana diubah dengan Republik Indonesia, Undang-Undang Nomor 8 tahun 2016 Tentang Penyandang Disabilitas.

[7] Lihat, Putusan, Mahkamah Agung Nomor: 595/K/TUN/2005 MA, Tentang Penolakan Penyandang Disabilitas Menjadi PNS di Kota Surabaya Tahun, 2005, pp. 11.

[8] Rozali Abdul Syamsir, Perkembangan HAM dan Keberadaan Peradilan HAM di Indonesia, Jakarta: PT. Ghalia Indonesia, 2002, pp. 69.
[9] Suparman Marzuki, Tragedi Politik Hukum HAM, Yogyakarta: Pustaka Pelajar bekerja sama dengan Pusham UII, 2011, Cetakan Pertama, pp. 294.

[10] Muladi, Hukum dan Hak Asasi Manusia, Jakarta: Gaya Media Pratama, 1996, pp. 292.

[11] H.R. Abdussalam, HAM Dalam Proses Peradilan, Jakarta: PTIK Press, 2010, pp. 57.

[12] A. Hamid S. Attamimi, Dikembangkan oleh Maria Farida Indrati S, dari Perkuliahan Ilmu Perundang-undangan, Jenis, Fungsi, dan Materi Muatan, Yogyakarta: Kanisius, 2007, pp.13.

[13] Philippe Nonet dan Philip Selznick, Hukum Responsif, Bandung: Penerbit Nusa Media, 2005, pp 49.

[14] Lihat, Pasal 4 Republik Indonesia, Undang-Undang Nomor 26 Tahun 2006 Tentang Pengadilan HAM

[15] Nin Yasmine Lisasih, Pembentukan Pengadilan HAM Di Indonesia Sebagai Suatu Proses Politik Hukum, Jakarta: Rieneka Cipta, 2002, pp. 23.

[16] Lihat, Penjelasan Republik Indonesia, Undang-Undang Undang-Undang Nomor 26 Tahun 2000 Tentang Pengadilan HAM.

[17] Lihat, Pasal 104 ayat (2) Republik Indonesia, Undang-Undang Nomor 39 Tahun 1999 Tentang Hak Asasi Manusia menyatakan "Pengadilan sebagaimana dimaksud dalam ayat (1) dibentuk dengan Undang-Undang dalam jangka waktu paling lama empat tahun". Maka tidak sampai empat tahun dengan tergesah-gesah pada tanggal 6 November 2000 disahkannya Republik Indonesia, Undang-Undang Nomor 26 Tahun 2000 Tentang Pengadilan HAM.

[18] Stewart Macaulay, et.all, Law And Society Readings On The Social Study Of Law, New York: W.W. Norton \& Company Inc, 1995, First Edition, pp. 387.

[19] Syawal Abdulajid dan Anshar, Pertanggung Jawaban Pidana Komando Militer Pada Pelanggaran Berat HAM, Yogyakarta: Laks Bang Pressindo, 2010, pp. 17.

[20] Achmad Ali, Menguak Teori Hukum (Legal Theory) dan Teori Peradilan (Judicial Prudence) Termasuk Interpretasi Undang-Undang (Legisprudence), Jakarta: Kencana Pranada Media Group, 2009, pp. 52.

[21] Lihat, Pasal 3 ayat (1) Republik Indonesia, Undang-Undang Nomor 26 Tahun 2000 tentang Pengadilan Hak Asasi Manusia.

[22] Peter De Cruz, Perbandingan Sistem Hukum Common Law, Civil Law dan Socialist Law, Jakarta: Penerbit Nusa Media, 2010, Cetakan Pertama, pp. 434.

[23] Lihat, Pasal 7 Republik Indonesia, Undang-Undang Nomor 26 tahun 2000 Tentang Pengadilan HAM.

[24] Mahrus Ali dan Syarif Nurhidayat, Penyelesaian Pelanggaran HAM Berat, Jakarta: Gramata Publishing, 2011, pp. 41-42.

[25] Titon Slamet Kurnia, Reparasi (Reparation) Terhadap Korban Pelanggaran HAM di Indonesia, Bandung: PT. Citra Aditya Bakti, 2006, pp. 67- 68.

[26] R. Wiyono, Pengadilan Hak Asasi Manusia di Indonesia, Jakarta: Kencana, 2006, pp. 14. 